\author{
Mehmet Akif Ersoy Üniversitesi Fen Bilimleri Enstitüsü Dergisi 12(1): 54-68 (2021) \\ The Journal of Graduate School of Natural and Applied Sciences of Mehmet Akif Ersoy University 12(1): 54-68 (2021)
}

Araştırma Makalesi / Research Paper

\title{
Uzaktan Eğitimin Uygulamalı Derslerde Sürdürülebilirliği: Mimarlık Bölümleri Örneği
}

\author{
Yaren ŞEKERCi (D) 1 , Hacer MUTLU DANACI ${ }^{(D)}$, Zuhal KAYNAKCI ELINÇ (D) 2* \\ ${ }^{1}$ Antalya Bilim Üniversitesi, Güzel Sanatlar ve Mimarlık Fakültesi, Antalya \\ ${ }^{2}$ Akdeniz Üniversitesi, Mimarlık Fakültesi, Antalya \\ Geliş Tarihi (Received): 03.02.2021, Kabul Tarihi (Accepted): 14.03.2021 \\ $\square$ Sorumlu Yazar (Corresponding author*): zuhalelinc@akdeniz.edu.tr \\ (C) +902422274480 등 +902423106213
}

ÖZ

1990'lardan beri mimarlık eğitiminin uzaktan verilebilmesine dair çalışmalar yapılmıştır; ancak bu çalışmalar, eğitimin tasarım stüdyosu ve teorik kısmıyla kısıtı kalmıştır. Uygulamalı derslerde, dünya genelindeki mimarlık eğitiminde yüz yüze eğitime devam etme eğilimi bulunmaktadır. Tasarım stüdyosu derslerindeki kritiklerde öğrenciler, son proje taslaklarını ders yürütücüsüne sunar, ders yürütücüsünün önerileriyle öğrencinin kritiği tamamlanır. Teknik derslerdeyse ders yürütücüleri çeşitli yöntemlerle anlatım yaparak öğrencilerin bu konuda bilgilenmesini sağlar ve öğrencilere çizim çalışmaları yaptırılarak konunun pekiştirilmesi amaçlanır. COVID-19 nedeniyle Mart 2020'de uzaktan eğitime geçilmesiyle birlikte, mimarlık eğitimi tüm derslerini çevrimiçi ortamlara taşımak durumunda kalmış ve uygulamalı dersler de toplantı uygulamaları aracılığıyla eş zamanlı gerçekleşmeye başlamıştır. Mimarlık bölümlerindeki uygulamalı derslerde uzaktan eğitim sisteminin, şartların normale dönmesiyle birlikte kısmen veya tamamen devam etmesi, mimarlık eğitiminde uzaktan eğitimin uygulamalı derslerdeki sürdürülebilirliği ile alakalıdır. Bu konu, mimarlık eğitiminin bundan sonraki sürecini yakından etkileyecektir. Mimarlık eğitiminde uzaktan eğitimin avantajları, dezavantajları, tehdit ve fırsatları, eksik veya geliştirilebilecek yönlerinin saptanması ve çeşitli altyapı yeterliliklerinin incelenmesi bu bağlamda önemli olmaktadır. Bu şartlar altında çalışmada, mimarlık öğrencileri ve ders yürütücüleriyle yarı yapılandırılmış anket çalışması yapılarak, Türkiye'deki üniversitelerdeki mimarlık eğitiminde uzaktan eğitimin uygulamalı derslerdeki sürdürülebilirliğinin araştırıması amaçlanmaktadır.

Anahtar Kelimeler: COVID-19, eğitimde sürdürülebilirlik, mimarlık eğitiminde uzaktan eğitim, uygulamalı dersler

\section{Sustainability of Distance Education in Applied Courses: The Case Study of Architecture Departments, Turkey}

\begin{abstract}
Since the 1990s, some studies have been carried out to ensure that distance architectural education can be maintained. However, these studies mostly remained for the design studio and the theoretical part of the education. In practical courses, there is a tendency to continue on the face-to-face education model in architectural education in the worldwide. In the critiques of the design courses, the students present their project drafts to the instructor, and the critique of the student is completed at the end of a critical process in which the instructor makes revision proposals. In technical courses, the course instructors give students information in certain ways, and it is aimed to reinforce the technique by asking students to do the drawing by themselves. Due to the COVID-19, architectural education had to move all courses online. The practical courses have started to take place through various meeting applications synchronically. As the conditions return to normal, the continuation of the distance education system partially or completely is related to the sustainability of distance education in the practical courses of the architectural education. This issue will closely affect the next process of architectural education. In this context, it is important to determine the advantages, disadvantages, threats and opportunities of distance education in architectural education, its deficiencies


or aspects that can be improved, and to examine various infrastructure competencies. Under these conditions, in this study, architecture students and the instructors have been asked with semi-structured questionnaires, in architectural education at universities in Turkey to investigate the viability of distance education in practical courses.

Keywords: COVID-19, sustainability in education, distance education in architecture, practical courses

\section{GíRiş}

Mimarlık alanındaki yazılı ilk teorik kitabın sahibi olan Vitruvius (2005)'a göre mimar, iyi yazabilmeli ve başta tarih, felsefe, müzik, tıp, hukuk ve astronomi olmak üzere birçok disiplinde de bilgili olmalıdır. Yalnızca bu kadar geniş spektrumlu bir eğitim almış ve kültürel anlamda kendini yetiştirmiş bir birey, "uygunluk" (decor) ve "doğruluk" ilkeleri bağlamında mimarlığı gerçekleştirebilir (Vitruvius, 2005). İyi bir mimar, aynı anda hem doğal becerilere sahip, hem de eğitilmeye açık olmalıdir (Vitruvius, 2005).

Matbaanın bulunmasından önce, sembolik değerleri barındırmasıyla mimari yapıtlar, okunan metinlerin görevini üstlenmiştir. Bilgi, mimarlıkta saklı olup, yapılar hafıza sarayları gibi görülmüştür. Aydınlanma dönemiyle birlikte, hafıza saraylarının yerini ansiklopedi (enkylios paideia) almış ve bilim, mimarlık yerine doğa ile ilişkilenmeye başlamıştır (Artun, 2018). Vitruvius (2005)'un mimarlık eğitiminde ortaya koyduğu yöntem de, ansiklopedi kavramı içinde ve sanat, bilim ve tekniğin birleşiminden oluşmaktadır.

17. yüzyıl sonrasında mesleki eğitimine karşı artan önemle birlikte akademiler kurulmuştur (Özsavaş Uluçay ve Kaptan, 2018). Bu bağlamda, mimarlık eğitimindeki ilk köklü değişiklik, "Güneş Kralı XIV. Louis"nin ülkedeki bilim ve sanat etkinliğini merkezileştirerek gücünü duyurma azmiyle 1671 'de kurdurduğu Kraliyet Akademileri'nde gerçekleşmiştir. Önceden süsleme, bezeme ve el işçiliğinin yoğun şekilde görüldüğü bir mimarlık ve mimarlık eğitimi varken, akademiyle birlikte bezemelerden arındırılmış bir mimarlığın eğitiminin haftada iki gün halka açık şekilde verileceği bir yol izlenmiştir. Lonca ve atölyelere alternatif olarak gelen Akademi, geleneksel mimarlık eğitimine üstünlüğünü klasik mimarlığın herkesçe kabul görmüş değerleriyle, eğitimin teorik bir altyapıya oturuşuyla ve eğitimin isteyen tüm kişiler için erişilebilir olmasıyla göstermiştir. Bu süreçte, atölye sistemi de korunmuş ve fakat eğitime kuramsal bir yaklaşımla zorunlu dersler ve konferanslar eklenmiştir (Keskin Balamir, 1985).

Fransız İhtilali sırasında yeniden düzenlenip 1819 'da Ecole des Beaux-Arts adıyla yeni bir statüye kavuşan okulun eğitim programının zamanla daha da zenginleşerek kimya, arkeoloji, idare, hukuk, maliye gibi konu- ları da kapsamıştır (Keskin Balamir, 1985). Modern mimarlık hareketi öncesindeki dönemde temel sanat eğitimi enerjisini ve yetkesini büyük ölçüde bu Paris'teki bir akademik eğitim geleneği olan Ecole des BeauxArts'tan almıştır. Beaux-Arts, temelleri 18. yüzyıl psikolojik tepki kuramlarına ve akademilerde kutsanıp baş tacı edilen Neoplatonik öğretinin yeniden ortaya çıkmasına kadar giden belli plan örgütleme ve biçim düzenleme ilkeleri öğretmektedir. Sanatın kendi içindeki zanaatsal ya da teknik yönlerden bağımsız olarak belirli ilkeleri olduğu düşüncesi, 19. yüzyılın sonuna kadar popülerliğini korumuştur (Colquhoun, 2005) ve bu yıllarda dünyanın birçok yerinde açılmış olan tasarım okullarında benimsenmiş ve uygulanmıştır.

Beaux-Arts eğitim programı, atölyeler ve sınıflar olmak üzere iki grup dersten meydana gelmektedir. Aslında bir üçüncü grup da bulunmaktadır ve bu grupta öğrencinin rekabet gücünü ve kişisel inisiyatif alma yeteneğini geliştirmek amaçlı aylık ve yıllık yarışmalar olmaktadır. Akademinin başlıca sorumluluğu sınıflarda verilecek dersleri ve yarışmaları düzenlemektir ve atölyeler okulun idari şemasından bağımsız olarak yirmi kadar öğrenciden talep gelmesi durumunda okulun eğitim kadrosunda da bulunan tanınmış bir mimar tarafından açılmaktadır. Atölye sisteminde usta-çırak ilişkisi öne çıkmakta ve yeni ve eski öğrenciler arasında örgütlü bir dayanışma bulunmaktadır (Keskin Balamir, 1985). Eğitim programında desen, perspektif, anatomi ve tarih dersleri yer almakta, 1863 yılından sonra resim, heykel, mimarlık ve gravür bölümleri ayrılmaktadır (Dilmaç, 2010; Özsavaş Uluçay ve Kaptan, 2018). Okulun hazırlıktan sonraki ilk sınıfında daha çok pratik eğitimi içermekte ve bu eğitimde taş, ahşap, metal, kil gibi malzemelerle çalışmalar yürütülmekteyken; ikinci sınıfında teknik yönden daha kuvvetli olan formel eğitim verilmektedir (Keskin Balamir, 1985).

Beaux-Arts ekolü tasarım eğitiminde etkin rolüne devam ederken, bir yandan yeni ekoller de oluşmaya başlamıştır ve bunların başında Ecole Polytechnic gelmektedir. Beaux-Arts ekolünün birikimi üzerine kurulsa da bu ekol, okuldaki ilk hoca olan Jean-Nicolas-Louis Durand tarafından tip planlar ve farklı çeşitlilikteki cephe tasarımlarıyla ekonomik ve uygun yapıların inşa edilmesi yönünde evrensel bir inşa yöntemi geliştirmiştir (Frampton, 1996). Bu da ileride modern mimari hareketiyle daha da öne çıkacak olan işlevselci bir duruşa doğru bir yönelimin başlangıcı olmaktadır. 
Sanayi Devrimi, birçok disipline etki ettiği gibi, içinde tasarımı barındıran disiplinleri ve bu disiplinlerin eğitimlerini de derinden etkilemiştir. Almanya'da kurulan Deustcher Werkbund, uygulamalı sanatlardaki daha sonradan Bauhaus olarak anılacak olan yeni hareketin liderliğini üstlenmiştir (Maciuika, 2019). Bauhaus; Avrupa'da başlayan, sanat, tasarım, mimarlık eğitiminde bir devrim niteliğinde kabul edilen, etkisi tüm dünyaya ve yalnızca 1919-1933 yılları arasında açık kalmış olmasına (Yorgancıoğlu, 2019) rağmen tüm zamana yayılan bir fikirler ya da kavramlar, değerler, teknikler ve modellerine kümesidir (Aközer, 2019). Bauhaus, sanat ve teknik/zanaatı bütüncül olarak ele alan bir tasarım eğitiminin peşindedir ve fakat endüstrinin standardizasyonu, ürünlerin tipikleştirilmesi fikriyle sanatsal kişiliğin geliştirilmesi düşüncelerinin sıcak ortamını oluşturmasıyla 20. yüzyılla birlikte öne çıkan çok sesliliğin arka planda kalmasına neden olan bir idealizme sahiptir (Özkar, 2019).

Günümüzde mimarlık eğitimi, merkezinde tasarım stüdyosu derslerinin bulunduğu, müfredatın diğer uygulamalı ve teorik derslerle bütüncül olarak kurgulandığı, lisans eğitimi sonrasında mezun kişinin mimarlık mesleğini icra edebileceği yeterliliğe erişmesini sağlayan bir eğitim haline gelmiştir. Uygulama ağırlıklı stüdyo eğitimi mimarlık eğitiminin omurgasını oluşturmakta ve uzun zamandır öncelikli konumunu korumaktadır. Alışılagelmiş sınıf senaryolarına kıyasla bu derslerin işlendiği "stüdyo" adı verilen sınıflar, öğrencilerin entelektüel ve sosyal olarak meşgul oldukları, çizim, maket yapma veya fikirler üzerinde tartışma gibi farklı etkinliklerde analitik, sentetik ve değerlendirici düşünme biçimleri arasında geçiş yaptığı aktif mekanlardır (Dutton, 1987). Tasarım stüdyoları derslerinde eğitim metotları olarak düşünsel ve formel metotlar kullanılmaktadır. Düşünsel metotlar; yaratıcı drama, metafor, enformel eğitim yöntemi-oyun, nitelik sıralama, zihin haritası, çağrışım tekniği, altı şapkalı düşünme tekniği, beyin fırtınası, Scamper, Harvey kartları, kavram haritası yöntemleri iken; formel eğitim metotları Juan Gris, dokuz kare grid, kural tabanlı biçim grameri, evrimsel tasarım- genetik algoritmalar, metin-biçim grameri, analitik ve blok problemi yöntemleridir (Onur ve Zorlu, 2017).

Mimarlık eğitiminde, birebir ve yaparak öğrenme önemlidir. Bu nedenle Chikering ve Gamson (1987)'in belirttiği üzere, öğrencilerin sınıfta sunum yapan hocalarını oturup dinledikleri bir eğitim modeli, mimarlık için uygun ve etkili olamamaktadır. Ancak öğrencilerin öğrenim sürecinin ana aktörü olduğu bir aktif öğrenmenin olumlu sonuçlar doğuracağı belirtilmektedir (Keyser, 2000). Bu bağlamda John Dewey ve Evelyn Dewey ta- rafından 1915 'te öğrencilerin ilgi ve dikkatlerini arttıracak bir eğitim modeli olan "yaparak öğrenme" geliştirilmiştir (Dewey ve Dewey, 1915) ve bu model, mimarlık eğitimde de önemli bir yere sahiptir. Yaparak öğrenmeye çabalayan ve bir ürün ortaya çıkarmayı hedefleyen mimarlık öğrencisi, eğitiminin amaçları doğrultusunda eş zamanlı gerçekleşen "tasarlama, yapma ve üretme" sürecinden en iyi şekilde faydalanmaktadır. Öte yandan "yaparak öğrenme" yöntemi, mimarlık mesleği gereği bir ekip çalışmasıyla topluluk halinde hareket etme sorumluluklarını öğrenciye yükler. Birbirleriyle etkileşim halinde olan öğrenciler, tasarım ve inşa etme süreçlerinde karşılaşılan zorluklarla da ekip halinde çözüm üretmektedir. Malzeme arayışı ve inşa sürecinin planlanması aşamalarında aktif roller sunan "yaparak öğrenme" yöntemi, bilgiyi deneyimlemek için teorik ve pratik arasında köprü niteliğindedir (Mun ve Arslan Selçuk, 2018).

1990'lardan beri, özellikle de bilgisayar destekli tasarım (CAD) programlarının öncelikle mimarlık ofislerinde daha sonra da mimarlık eğitiminde yer edinmeye başlamasıyla ve internetin evlere dahi girecek kadar yaygınlaşmasıyla birlikte (Öztoprak, 2004) tasarım eğitiminin uzaktan şekilde çevrimiçi ortamlarda verilebilmesine dair girişimlerde bulunulmuştur (Wojtowicz, 1995; Cini ve Vilic, 1999; Bender, 2003; Shao ve ark., 2007). Bu çalışmalar yalnızca tasarım stüdyosu ve teorik dersler özelinde gerçekleştirilmiş olup mimarlık eğitiminin diğer uygulamalı ve teknik derslerinin çevrimiçi öğretilmesine yönelik detaylı bir çalışma bulunmamaktadır. Mimarlık eğitiminin ana omurgasını oluşturan tasarım stüdyolarında eğitim özellikle öğrenciler çalışıp üstüne yeniden çalıştıkları, çizip yeniden çizdikleri, kısacası sürekli olarak tasarımlarını yeniden gözden geçirdikleri bir süreci getirir. Günlük kritikler, hem eğitimciler hem de öğrencilerin sürekli incelemeleri ve revizyonlarından oluşan bir süreçte devam eder (Fichera, 2012). Proje derslerindeki yüz yüze kritiklerde öğrenciler, çıktı aldıkları son proje taslaklarını ders yürütücüsüne sunar, ders yürütücüsünün üzerinde düzeltmeler yaptığı ve notlar aldığı bir kritik süreci sonunda öğrencinin kritiği o ders için tamamlanır.

Mimarlık terimi olarak kullanıldığında bir yapının ya da yapının herhangi bir bölümünün hangi malzemeyle ve nasıl inşa edileceğini, mühendislik terimi olarak kullanıldığında bir makinenin veya parçalarının iç mimarlık terimi olarak kullanıldığında mekanların ve mobilya donatılarının imalat veya inşasının nasıl yapılacağını konusunda uzman kişilere eksiksiz olarak plan, kesit, görünüş ve perspektif halinde ölçekli çizimlerle anlatımını ifade eden disiplinler arası mesleki bir iletişim dili olan teknik resim (TDK, 2011; Hasol ve Polatoğlu, 2019) 
gibi uygulamalı derslerinde ise ders yürütücüleri konuları ya tahtada çizerek, ya maketle veya önceden tamamlanmış çizimler üzerinden anlatım yaparak öğrencilerin bu konuda bilgilenmesini sağlar. Ders anlatımı sonunda öğrencilere çizim çalışmaları yaptırılarak konunun pekiştirilmesi amaçlanır. Geleneksel yüz yüze eğitimde uygulamalı dersler, genellikle kağıtlara T cetveli ve kalemlerle el çizimi yöntemiyle gerçekleştirilebildiği gibi, bazı üniversitelerde CAD programlarıyla da yaptırımaktadır. Bu tip, ders yürütücüsü ve öğrencinin eşzamanlı bir biçimde iletişim kurmasının, tasarım ve teknik çizimlerin üzerinde tartışmasının gerektiği uygulamalı derslerde, dünya genelindeki mimarlık eğitiminde geleneksel yüz yüze eğitim modelinde devam etme eğilimi hakimdir.

Dünya Sağlık Örgütü'ne göre ilk olarak 2019 yılında Çin'in Wuhan kentinde ortaya çıkan ve SARS-CoV-2 adı verilen yeni bir koronavirüsün neden olduğu bir hastalık olan COVID-19 pandemisi, bir dizi "viral pnömoni" vakası raporunun ardından tespit edilmiş (URL$1,2020)$ ve o günden itibaren küresel ölçekte tüm insanlığı etkilemiştir. Bu pandemi yüzünden Türkiye'de tüm üniversiteler öncelikle 16 Mart 2020'de Yüksek Öğretim Kurumu (YÖK)'ün kararıyla üç haftalık tatile girmiş, sonrasında şartlar gereği zorunlu olarak tamamen uzaktan eğitime geçilmiştir. 2019-20 bahar dönemine denk gelen bu süreç, Türkiye'de mimarlık bölümlerini ikiye bölmüş olup, bazı üniversitelerin mimarlık bölümleri hızlı adaptasyon özellikleri göstererek öğrenci ve eğitimcinin katılımıyla eş zamanlı bir şekilde çeşitli toplantı uygulamaları aracılığıyla çevrimiçi platformlarda uzaktan eğitime başlamıştır. Diğerleri ise, sürecin geçici olabileceğini umarak, eğitimin yalnızca teorik kısmını “Öğrenme Yönetim Sistemleri” (LMS: Learning Management System) üzerinden devam ettirmiş, uygulamalı kısımları üniversitelerin yazın açılacağı öngörülerek yaza bırakılmıştır. Pandeminin, tahmin edilen şekilde kontrol altına alınamaması nedeniyle uzaktan eğitimin devam etmesiyle birlikte yaz dönemiyle birlikte artık tüm üniversitelerin mimarlık bölümleri uygulama/teorik ayrımı yapmadan tüm eğitim sistemlerini uzaktan eğitime adapte ederek çeşitli çevrimiçi toplantı araçlarıyla sürdürmektedir. Her ne kadar günümüzün üniversite öğrencileri, dijital dünyanın içinde büyüyen $Z$ kuşağı olsa da, bu öğrencilerin ve eğitimcilerin geleneksel eğitim modeline alışkın olması ve mimarlık eğitiminin yüz yüze uygun şekilde tasarlanmış olması nedenleriyle, olağanüstü şartlarla zorunlu olarak geçilen uzaktan eğitim yöntemi başta çoğunluğa yabancı gelmiştir. Ancak Türkiye'de üniversitelerin uzaktan eğitime yaklaşık bir senedir devam etmesiyle 2021 yılı itibariyle eğitimin içindeki tüm aktörlerin adapte olduğu bir durum haline gelmiştir. Gelecekte pandemiye aşı vb. yollarla çözüm bulunmasıyla ve şartların normale dönmesiyle birlikte, Türkiye'deki üniversitelerin mimarlık bölümlerinde teorik dersler istenirse kolaylıkla uzaktan eğitim yöntemiyle devam ettirilebilecektir. Çünkü teorik dersler, ders yürütücüsü ve öğrencinin eşzamanlı olarak üzerinde tartışmasına gerek olmadan da, dosya paylaşımlarıyla asenkron şekilde gerçekleştirilebilmektedir. Mimarlık eğitiminin uzaktan devam ettirilmesindeki asıl zorluk, ders yürütücüsü ve öğrencinin eşzamanlı iletişim kurup, uygulamalar ve projeler üzerinde tartışabilmesi, ders yürütücüsünün öğrencinin ekranına erişebilmesi, çizimler üzerinde hızlı eskizler yapıp kritik verebilmesi ve düzeltmeler yapabilmesindedir.

Uzaktan eğitim modeli Türkiye'de üniversitelerin lisans programlarında pandemi sonrası uygulanmaya başlasa da aslında 1980 yıllardan bu yana dünyada tartışılan bir modeldir. Keegan (1980) uzaktan eğitim kavramını altı temel bileşen ile açıklamaktadır, bunlardan öğretmen, öğrenci ve öğrenme grubunun farklı ortamlarda bulunması, teknolojik araçların uzaktan eğitimdeki yeri ve iki yönlü iletişimin sağlanması, eğitim kurumunun buradaki rolü uzaktan eğitimin niteliğini belirlemede önem kazandırmaktadır (Doğan ve ark., 2012).

Mimarlık eğitiminde uygulamalı derslerde uzaktan eğitim sisteminin, şartların normale dönmesiyle birlikte kısmen veya tamamen sürdürülebilirliği, uzaktan eğitimin avantajları, dezavantajları, uygulamalı derslerdeki tehdit ve fırsatları, eksik veya geliştirilebilecek yönlerinin saptanması, öğrenci ve ders yürütücülerinin teknolojik olanak ve bilgi seviyeleri ve ülkenin internet ve elektrik altyap yeterlilikleriyle ilgilidir. Bu parametrelerin incelenmesi, mimarlık eğitiminin bundan sonraki sürecini yakından etkileyecektir. Bu şartlar altında çaıışmada, mimarlık öğrencileri ve ders yürütücüleriyle yarı yapılandırılmış anket çalışması yapılarak, mimarlık eğitiminde uzaktan eğitimin uygulamalı derslerdeki sürdürülebilirliğinin araştırılması amaçlanmaktadır. Çalışma, Türkiye internet ve elektrik altyapısına dair incelemeler de içerdiğinden, kapsam Türkiye ölçeğinde tutulmuştur.

\section{MATERYAL VE YÖNTEM}

Çalışmanın akış şeması Şekil 1'deki gibidir. Giriş bölümünde çalışma için gerekli olan literatür taraması yapılmış olup, konu ve kapsamı belirlenerek ifade edilmiştir. Literatür taramasıyla ve konu ve kapsamın belirlenmesiyle birlikte uygun örneklem grubunun ve araştırma yönteminin tespiti sonucunda araştırma gerçekleştirilecek ve veriler toplanarak analiz edilecektir. 
Uzaktan Eğitimin Uygulamalı Derslerde Sürdürülebilirliği: Mimarlık Bölümleri Örneği

\begin{tabular}{|c|}
\hline Çalışma için gerekli literatür taramasının yapılması \\
\hline Çalışmanın konu ve kapsamının belirlenmesi \\
\hline Çalışmanın örneklem grubunun tespiti \\
\hline Konuya uygun araştırma yönteminin tespiti \\
\hline Araştırma yönteminin örneklem grubuna uygulanması ve veri toplama \\
\hline Toplanan verilerin uygun analiz yöntemiyle analizi, bulgular \\
\hline Yapılan analizlerin tartışılması \\
\hline
\end{tabular}

Şekil 1. Çalışmanın akış şeması

\section{Örneklem Grubu-Katılımcılar}

Çalışma, mimarlık bölümlerindeki uygulamalı derslerin uzaktan eğitimdeki sürdürülebilirliğini araştırmak amacıyla gerçekleştirildiği için, çalışma mimarlık bölümü öğrencileri ve öğretim elemanlarından oluşan iki örneklem grubunun katılımıyla gerçekleştirilmiştir.

Birinci örneklem grubunda, Akdeniz Üniversitesi (266), Antalya Bilim Üniversitesi (29), Sakarya Üniversitesi (3) ve Eskişehir Teknik Üniversitesi (1)'nde mimarlık okuyan 299 öğrenci bulunmaktadır. Öğrencilerin sınıflara göre dağılımı oldukça dengeli olup çalışmaya katılan birinci, ikinci, üçüncü ve dördüncü sınıf mimarlık öğrenci sayıları sırasıyla $83,73,79$ ve 64 'tür.

İkinci örneklem grubunda ise, Türkiye'deki üniversitelerin mimarlık bölümlerinden öğretim elemanları bulunmaktadır. 2021 itibariyle Türkiye'de 102 üniversitede mimarlık bölümü bulunmaktadır. Bunlardan 73'ünün bünyesinde bulunan öğretim elemanlarından toplam 1449 kişiye e-posta aracılığıyla ulaşılmış, 51 üniversiteden toplam 123 öğretim elemanı, e-postalarına gönderilmiş anketi yanıtlayarak çalışmaya dahil olmuş ve ikinci örneklem grubunu oluşturmuştur (Tablo 1). İkinci örneklem grubundaki öğretim elemanlarının 52'si 25-34, 42'si 3544,15 'i 45-54, 11'i 55-64 ve 3'ü 65 ve üstü yaş aralığındadır.

\section{Veri Toplama Yöntem ve Aracı}

Birinci örneklem grubu olan mimarlık öğrencilerine 24 adet 5'li likert ölçeğinde, 2 adet çoktan seçmeli, 1 adet de kısa yanıtlı sorudan oluşan toplam 27 soru yöneltilmiştir. Sorular, çalışmanın amaç ve kapsamına en uygun olacak şekilde üç ana konu başığı göz önüne alınarak hazırlanmış olup, bu başlıklar Türkiye internet ve elektrik altyapısı, öğrenci ve öğretim elemanlarının teknolojik olanakları ve bilgi yeterlilikleri ve genel sorulardır.
İkinci örneklem grubu olan mimarlık bölümü öğretim elemanlarına ise, mimarlık öğrencilerinkinden daha kapsamlı bir anket çalışması hazırlanmış olup, yine aynı konu başlıkları içerisinde öğretim elemanlarına 30 adet 5 'li likert ölçeğinde, 5 adet çoktan seçmeli, 1 adet çoklu seçenek işaretlemeli, 2 adet de kısa yanıtlı sorudan oluşan toplam 38 soru yöneltilmiştir. Bu sorulardan bazıları, öğretim elemanlarının mimarlık öğrencilerinin uzaktan eğitim sürecindeki deneyimlerine dair gözlem ve görüşlerine yönelik hazırlanmışken, bir kısmı da öğretim elemanı olarak kişinin kendisinin mimarlıkta uzaktan eğitime dair deneyim ve görüşleri üzerine olmuştur.

Google Forms üzerinden hazırlanan anketler, mimarlık öğrencilerine ve öğretim elemanlarına mail aracılığıyla anket linki gönderilerek ulaştırılmıştır. Katılımcılara, ankete katılmaktan istedikleri an vazgeçebilecekleri, bilgilerinin gizli tutulacağı ve herhangi bir kişi, kurum ve kuruluşla paylaşılmayacağı belirtilmiş, çalışmanın içeriği ve amacı hakkında kısaca bilgi verilmiştir.

\section{Veri Analiz Yöntemi ve Çalışmanın Güvenilirliği}

Birinci ve ikinci örneklem grubuna Google Forms üzerinden yapılan anketlerin tüm verileri SPSS programına girilerek analiz edilmiştir. Çalışmanın güvenilirliğini arttırmak adına öğrenci anketinde 10. ve 16. sorular kontrol soruları olarak hazırlanmış olup, bu sorulara öğrencilerin verdiği yanıtlar kontrol edilerek, anketi önemsemeyerek yapanların tespit edilip, çalışmanın örneklem grubundan çıkarılması sağlanmıştır. Bu kontrol yöntemiyle birlikte, 299 öğrencilik birinci örneklem grubundan 15 öğrenci, çalışmadan çıkarılmış olup, birinci örneklem grubundan çalışmaya dahil edilen öğrenci sayısı 284 olmuştur. Öğretim elemanları için yapılan anket çalışmasında, kitlenin bilinçli olduğu göz önüne alınarak, buna gerek görülmemiştir. 
Uzaktan Eğitimin Uygulamalı Derslerde Sürdürülebilirliği: Mimarlık Bölümleri Örneği

Tablo 1. İkinci örneklem grubundaki mimarlık öğretim elemanları ve öğretim elemanlarının üniversitelere göre dağılımı

\begin{tabular}{|c|c|c|c|c|c|}
\hline Üniversite Adı & $\begin{array}{l}\text { İletişime } \\
\text { geçilen } \\
\text { öğretim } \\
\text { elemanı } \\
\text { sayısı }\end{array}$ & $\begin{array}{l}\text { Çalışmaya } \\
\text { katılan öğre- } \\
\text { tim elemanı } \\
\text { sayısı }\end{array}$ & Üniversite Adı & $\begin{array}{l}\text { İletişime } \\
\text { geçilen } \\
\text { öğretim } \\
\text { elemanı } \\
\text { sayısı }\end{array}$ & $\begin{array}{l}\text { Çalışmaya } \\
\text { katılan öğre- } \\
\text { tim elemanı } \\
\text { sayısı }\end{array}$ \\
\hline Abdullah Gül Üniv. & 24 & 4 & $\begin{array}{l}\text { Izmir Yüksek Teknoloji Ensti- } \\
\text { tüsü }\end{array}$ & 53 & 3 \\
\hline Akdeniz Üniv. & 14 & 6 & Işık Üniv. & 6 & 2 \\
\hline Altınbaş Üniv. & 8 & 1 & Kadir Has Üniv. & 15 & - \\
\hline Antalya Bilim Üniv. & 12 & 4 & Karabük Üniv. & 24 & 3 \\
\hline Atatürk Üniv. & 14 & - & Karadeniz Teknik Üniv. & 56 & 4 \\
\hline Atılım Üniv. & 13 & 1 & Kırklareli Üniv. & 9 & - \\
\hline Bahçeşehir Üniv. & 24 & 2 & Kocaeli Üniv. & 21 & 2 \\
\hline Beykoz Üniv. & 2 & - & Konya Teknik Üniv. & 39 & 6 \\
\hline Beykent Üniv. & 1 & 1 & KTO Karatay Üniv. & 9 & 2 \\
\hline Bursa Teknik Üniv. & 12 & - & Manisa Celal Bayar Üniv. & 5 & - \\
\hline Doğuş Üniv. & 17 & 3 & Mardin Artuklu Üniv. & 16 & 2 \\
\hline Dokuz Eylül Üniv. & 50 & 2 & Mersin Üniv. & 8 & - \\
\hline Düzce Üniv. & 12 & 1 & $\begin{array}{l}\text { Mimar Sinan Güzel Sanatlar } \\
\text { Üniv. }\end{array}$ & 55 & 7 \\
\hline Erciyes Üniv. & 27 & 3 & Muğla Sıtkı Koçman Üniv. & 7 & 2 \\
\hline Eskişehir Teknik Üniv. & 17 & - & Munzur Üniv. & 3 & - \\
\hline $\begin{array}{l}\text { Fatih Sultan Mehmet Vakıf } \\
\text { Üniv. }\end{array}$ & 68 & 5 & Necmettin Erbakan Üniv. & 9 & 2 \\
\hline Gazi Üniv. & 74 & 1 & Niğde Ömer Halisdemir Üniv & 6 & 1 \\
\hline Gaziantep Üniv. & 9 & - & Nişantaşı Üniv. & 9 & 1 \\
\hline Gebze Teknik Üniv. & 39 & 3 & Nuh Naci Yazgan Üniv. & 14 & 2 \\
\hline Haliç Üniv. & 11 & 1 & Ondokuz Mayıs Üniv. & 15 & 2 \\
\hline Harran Üniv. & 6 & - & Orta Doğu Teknik Üniv. & 3 & - \\
\hline Hasan Kalyoncu Üniv. & 15 & 1 & Pamukkale Üniv. & 8 & - \\
\hline Hatay Mustafa Kemal Üniv. & 10 & 1 & Recep Tayyip Erdoğan Üniv. & 8 & - \\
\hline $\begin{array}{l}\text { İhsan Doğramacı Bilkent } \\
\text { Üniv. }\end{array}$ & 7 & 1 & Sakarya Üniv. & 30 & 2 \\
\hline İskenderun Teknik Üniv. & 8 & - & Sivas Cumhuriyet Üniv. & 9 & 1 \\
\hline İstanbul Üniv. & 14 & 1 & Siirt Üniv. & 6 & - \\
\hline İstanbul Arel Üniv. & 15 & 1 & Süleyman Demirel Üniv. & 19 & - \\
\hline İstanbul Ayvansaray Üniv. & 4 & - & TED Üniv. & 18 & - \\
\hline İstanbul Bilgi Üniv. & 26 & 3 & Tekirdağ Namık Kemal Üniv. & 4 & 1 \\
\hline İstanbul Esenyurt Üniv. & 6 & - & Toros Üniv. & 10 & 1 \\
\hline İstanbul Gedik Üniv. & 7 & - & Trakya Üniv. & 33 & 4 \\
\hline İstanbul Gelişim Üniv. & 16 & 2 & Van Yüzüncü Yıl Üniv. & 16 & 2 \\
\hline İstanbul Medipol Üniv. & 22 & 4 & Yaşar Üniv. & 23 & 1 \\
\hline İstanbul Teknik Üniv. & 125 & 1 & Yeni Yüzyıl Üniv. & 5 & - \\
\hline İstanbul Ticaret Üniv. & 15 & 3 & YıIdız Teknik Üniv. & 62 & 2 \\
\hline İstinye Üniv. & 28 & 1 & Yozgat Bozok Üniv. & 14 & 1 \\
\hline İzmir Ekonomi Üniv. & 30 & 7 & Bilinmeyen & - & 3 \\
\hline
\end{tabular}

\section{BULGULAR}

Beş ayrı kategoride iki örneklem grubuna da ayrı ayrı sorulmuş olan anket soruları analiz edilmiştir. Beş kategoride verilen cevaplar tablolar haline getirilirken tüm tablolarda "kesinlikle katılıyorum (1)" ve "katılıyorum (2)" yanıtları olumlu (+), "katılmıyorum (4)" ve "kesinlikle katımıyorum (5)" yanıtları da olumsuz (-) yanıtlar olarak birer başlık altında toplanmıştır.

Çalışmada ilk olarak, birinci kategori olan Türkiye'nin internet ve elektrik altyapısına dair öğrenci ve öğretim elemanlarına yöneltilmiş 7 soru analiz edilmiştir (Tablo 2).
Buna göre, öğrencilerin \%80'inden fazlası (228) mimarlık bölümlerinde aldıkları uzaktan eğitim esnasında internet kesilmeleri ve/veya yavaşlaması, \%64'ü (181) elektrik kesilmeleri nedeniyle altyapı sorunu yaşadıklarını belirtmiştir. Öğrencilerin \%25'i (72) internet ve \%18'i (51) elektrikle ilgili alt yapı problemlerine kendilerinin ek çözüm bulabildiklerini belirtmişse de, başta internet altyapısında sorun yaşayan \%80'lik (228) gruptan yalnızca 31'i ve elektrik altyapısında sorun yaşayan \%64'lük (181) gruptan yalnızca 20'si ek çözüm yolu bularak sorunlarını çözebildiklerini belirtmiş olup, altyapı problemlerini ek çözüm önerisiyle çözdüğünü belirten diğer öğrenciler, altyapı anlamında çok da sorun yaşamadığını 
belirtenlerdir. Öğrencilerin \%69'u (197) internet ve $\% 57$ 'si (161) elektrik altyapı sorunlarına çözüm üretememekte ve sorun yaşamaktadır.

Çalışmaya katılan öğretim elemanlarının \%71'i (87) uzaktan eğitim esnasında internet kesilmeleri ve/veya yavaşlaması, ve \%51'i (63) elektrik kesilmeleri nedeniyle altyapı sorunu yaşadıklarını belirtmiştir. Öğretim elemanlarından \%42'si (52) internet ve \%24'ü (29) elektrik elektrikle ilgili alt yapı problemlerine kendilerinin ek çözüm bulabildiklerini belirtmişse de, başta internet altyapısında sorun yaşayan \%71'lik (87) gruptan 52'si ve elektrik altyapısında sorun yaşayan \%51'lik (63) gruptan 29'u ek çözüm yolu bularak sorunlarını çözebildiklerini belirtmiş olup, altyapı problemlerini ek çözüm önerisiyle çözdüğünü belirten diğer öğretim elemanları, altyapı anlamında çok da sorun yaşamadığını belirtenlerdir. Öğretim elemanlarının \%28'i (34) internet ve \%28'i (34) elektrik altyapı sorunlarına çözüm üretememekte ve altyapı nedeniyle sorun yaşamaktadır. Yüzdelik bazında karşılaştııılığında, mimarlık öğretim elemanları internet ve elektrik alt yapısı konusunda, mimarlık öğrencilerine göre neredeyse yarı yarıya oranla daha az sorun yaşamakta ve sorunlara daha çözümsel yaklaşabilmektedir.

Öğrencilerin \%55’i (167) ve öğretim elemanlarının \%65’i (80) eş zamanlı yapılması gereken uygulamalı dersler sırasında yavaş internet hızı nedeniyle eşzaman problemi yaşamıştır. Sınav/ders/jüri/teslim esnasında öğrencilerin \%88'i (249) ve öğretim elemanlarının \%63'ü (77) internet; öğrencilerin \%85'i (241) ve öğretim elemanlarının \%63'ü (77) elektrik kesintisi yaşama intimali nedeniyle strese girmektedir. Bu oranlar, mimarlığın uygulamalı derslerinin iki aktörü tarafından da yüksek çıkmaktadır. Bu nedenle mimarlıkta uzaktan eğitimin uygulamalı derslerde sürdürülebilirliği, ülkedeki internet ve elektrik altyapısının geliştirilmediği noktada çok mümkün görünmemektedir. Bu çalışma Türkiye'deki mimarlık öğrencilerine ve öğretim elemanlarına yapılmış olsa da pandemiyle birlikte aslında tüm dünyada elektrik ve internet altyapısı sorun yaratmıştır. Normalin çok üstünde bir şekilde yüklenilen bu altyapılar, gün geçtikçe geliştirilmektedir.

Tablo 2. Türkiye internet ve elektrik altyapısına dair öğrenci ve öğretim elemanlarına yöneltilen anket soruların ana-

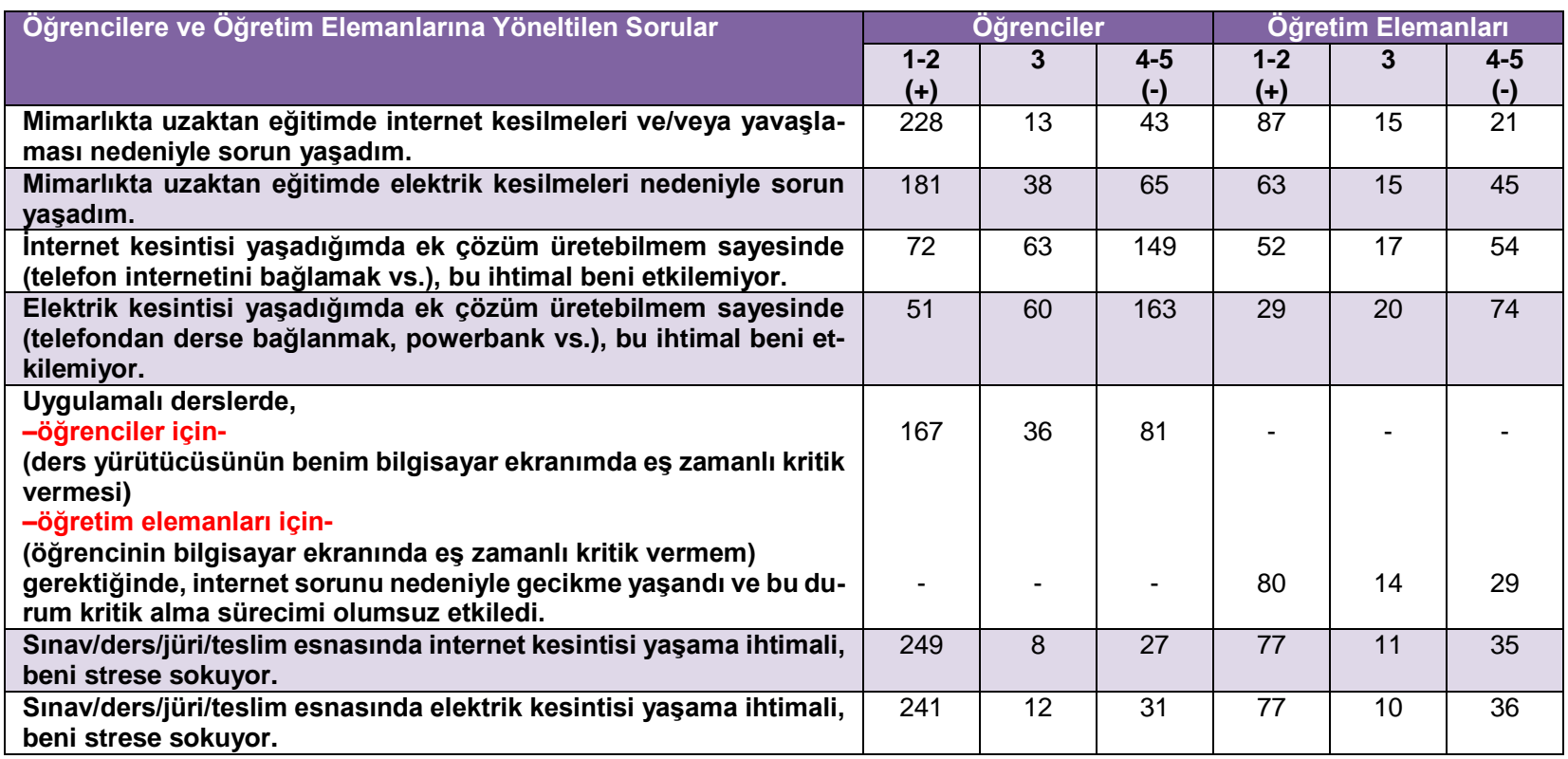

Anketin birinci kısmına ait bulgular mimarlıkta uygulamalı derslerin uzaktan eğitimi bağlamında olumsuz bir sonuç gösterse de, ikinci kısımdaki bulgular sürdürülebilirlik anlamında çok daha olumlu bir tablo çizmektedir. Çalışmanın ikinci kısmında, teknolojik olanaklarına ve bilgi yeterliliklerine dair yöneltilmiş olan öğrencilere 2 ve öğretim elemanlarına 3 sorunun analizi yapılmıştır (Tablo 3).
Buna göre, öğrenci ve öğretim elemanlarının teknolojik olanakları ve bilgi yeterliliklerinin incelendiği ikinci kısımda, öğrencilerin \%64'ü (182) ve öğretim elemanlarının \%76'sı (93) mimarlıkta uzaktan eğitim için yeterli özelliklere sahip bilgisayarlarının olduğunu belirtmekteyken, öğrencilerin \%12'si (33) ve öğretim elemanlarının \%13'ü (16) kararsız kalmıştır. Olumsuz yanıt verenler düşük bir oranda kalmış olsa da, öğrencilerin yaklaşık 4 'te 1'inin (69) ve öğretim elemanlarının yaklaşık 10'da 
birinin (\%11-14) mimarlıkta uzaktan eğitimde kullanabilecek yeterlilikte bilgisayarı bulunmamaktadır.

Öğrencilerin \%56'sı (160) öğretim elemanlarının uzaktan eğitim sürecini rahatça yönetecek ve uygulamalı derslerde ve tasarım stüdyosunda dersimde eşzamanlı ders yapabilecek teknoloji bilgisi yeterliliğine sahip olduğunu belirtirken, mimarlık öğretim elemanlarına bu soru uygulamalı dersler ve tasarım stüdyosu dersleri için ayrı ayrı sorulmuştur. Öğretim elemanlarının \%81'i (100) uygulamalı derslerde ve \%63'ü (77) tasarım stüdyosu derslerinde kendilerinin uzaktan eğitim sürecini rahatça yönetecek ve eşzamanlı ders yapabilecek teknoloji bilgisi yeterliliğine sahip olduğunu ifade etmiştir. Bu bağlamda, öğretim elemanları bilgisayar teknolojileri konusunda kendilerini, öğrencilerinin öğretim elemanlarını gördüğünden daha bilgili ve başarılı bulmaktadır. Ancak hem çalışmanın ilk kısmında da ortaya çıktığı gibi, internet ve elektrik altyapısından dolayı yaşanan sorunlar ve öğrencilerin öğretim elemanlarının bilgisini algılayabilecek yeterlilikle olamaması intimali, bu sonuçlardaki farklıları açıklayabilmektedir. Bununla birlikte, öğretim elemanlarının tasarım stüdyosu dışındaki uygulamalı derslerde kendilerini teknolojik bakımından daha yetkin gördüğü de anlaşılmaktadır.

Tablo 3. Öğrenci ve öğretim elemanlarının teknolojik olanakları ve bilgi yeterliliklerine dair öğrenci ve öğretim elemanlarına yöneltilen anket soruların analizi

\begin{tabular}{|c|c|c|c|c|c|c|}
\hline \multirow[t]{2}{*}{ Öğrencilere ve Öğretim Elemanlarına Yöneltilen Sorular } & \multicolumn{3}{|c|}{ Öğrenciler } & \multicolumn{3}{|c|}{ Öğretim Elemanları } \\
\hline & $\begin{array}{l}1-2 \\
(+)\end{array}$ & 3 & $\begin{array}{c}4-5 \\
(-)\end{array}$ & $\begin{array}{l}1-2 \\
(+)\end{array}$ & 3 & $\begin{array}{c}4-5 \\
(-)\end{array}$ \\
\hline Uzaktan eğitim için yeterli özelliklere sahip bir bilgisayarım var. & 182 & 33 & 69 & 93 & 16 & 14 \\
\hline $\begin{array}{l}\text {-öğrenciler için- } \\
\text { Uygulamalı derslerdeki ve tasarım stüdyosu dersindeki hocala- } \\
\text { rımın teknolojik bilgileri yeterliydi. Kolayca ekranıma erişim } \\
\text { sağladılar. } \\
\text {-öğretim elemanları için- }\end{array}$ & 160 & 60 & 64 & - & - & - \\
\hline $\begin{array}{l}\text { Uygulamalı derslerde ders anlatımı için gerekli teknolojik bil- } \\
\text { giye ve yeterliliğe sahiptim. Kolayca kendi ekranımı paylaşıp } \\
\text { ders içeriğimi aktardım. }\end{array}$ & - & - & - & 100 & 14 & 9 \\
\hline $\begin{array}{l}\text {-öğretim elemanları için- } \\
\text { Proje derslerinde kritik vermek için gerekli teknolojik bilgiye ve } \\
\text { yeterliliğe sahiptim. Uzaktan eğitimde kolaylıkla öğrencinin paf- } \\
\text { talarına erişim sağlayarak ve çizerek kritik verdim. }\end{array}$ & - & - & - & 77 & 19 & 27 \\
\hline
\end{tabular}

Çalışmada katılımcılara yöneltilen anket sorularının üçüncü aşamasında öğrencilere ve öğretim elemanlarına mimarlıkta uzaktan eğitimin uygulamalı derslerdeki sürdürülebilirliğini ölçmek amacıyla evde konsantrasyon sorunlarına ve ev şartlarının uygunluğuna dair sorular yöneltilmiştir ve bu sorulara verilen yanıtlar analiz edilmiştir (Tablo 4). Buna göre, öğrencilerin \%64'ü (183) mimarlıkta uzaktan eğitimde uygulamalı derslere rahat ev ortamından girmeleri nedeniyle konsantrasyon sorunu yaşadıklarını ve \%52'si (147) bu durumun uygulamalı derslerdeki performanslarını olumsuz etkilediğini belirtmiştir. Öğretim elemanlarının \%64'ü (79) de öğrencilerin mimarlıkta uzaktan eğitimde uygulamalı derslere rahat ev ortamından girmeleri nedeniyle konsantrasyon sorunu yaşadıklarını ve bu durumun öğrencilerin \%52'sinin (64) uygulamalı derslerdeki performanslarını olumsuz etkilediğini belirtmiştir. Burada çıkan sonuçlarda, mimarlık öğrencileri ve öğretim elemanları neredeyse tamamen aynı görüşte olup, evin rahat ortamında ders yapımasının öğrencilerin en az yarısının performansını ve konsantrasyonunu olumsuz etkilediğini belirtmiştir. Durumu bir de öğretim elemanı tarafından değerlendirmek gerekirse, mimarlık öğretim elemanlarının \%49'u (60) derslere rahat ev ortamından girmelerinin kendilerinin uygulamalı derslerdeki performanslarını olumsuz etkilediğini belirtmiştir.

Bununla birlikte mimarlık öğrencilerinin \%68'i (194) mimarlıkta uzaktan eğitimde derslerdeki konsantrasyon sürelerinin azaldığını ve dikkatlerinin yüz yüze eğitime göre daha hızlı dağıldığını belirtirken, öğretim elemanlarının \%63'ü (78) de öğrencilerin mimarlıkta uzaktan eğitimde derslerdeki konsantrasyon sürelerinin azaldığını ve dikkatlerinin yüz yüze eğitime göre daha hızlı dağıldığını ifade etmiştir. Bu aşamada öğretim elemanlarının bu konuda herhangi bir sorun yaşayıp yaşamadığı sorulmuş ve buna göre öğrencilere göre daha az bir oran çıksa da öğretim elemanlarının da \%31'inin uzaktan eğitimde derslerdeki konsantrasyon sürelerinin azaldığını ve dikkatlerinin yüz yüze eğitime göre daha hızlı dağıldığını belirtmiştir. Öğretim elemanlarından dikkatinin dağıldığını ve konsantrasyon sorunu yaşadıklarını belirtenlerin (22) yaşları genelde 25-34 yaş aralığında olup, 3544 yaş aralığında olanlarda sayı 9, 45-54 aralığında olanlarda 5 ve 55-64 aralığında olanlarda 2 olmaktadır; 65 ve üstü yaş grubundan olan katılımcılar (3) konsantrasyon sorunu yaşamamıştır. Çalışmaya katılanların \%42'si (52) 25-34 olan en genç yaş aralığında olsalar 
da, oranlandığında, daha ileri yaşlardaki öğretim elemanlarının uzaktan eğitimde daha az konsantrasyon sorunu yaşadığı anlaşılmaktadır.

Uzaktan eğitimin bir dezavantajı olarak eğitim eşitliğinin ortadan kalkması problemi karşımıza çıkmaktadır. Bulundukları şehir, ilçe, köy vb. coğrafik alan dolayısıyla elektrik ve internet altyapısıyla ve teknolojik olanaklarla ilgili bulgularda da kendini gösteren uzaktan eğitimdeki eğitim eşitsizliği durumu, öğrencilerin ev şartlarının birbiriyle aynı olmamasında daha da net ortaya çıkmaktadır. Yüz yüze eğitimde sınıf ve stüdyo ortamlarında herkes eşit şartlarda eğitim görürken, uzaktan eğitimde evin koşullarının herkes için farklılık yaratması da büyük bir dezavantaj doğurmaktadır. Birinci örneklem grubunu oluşturan mimarlık öğrencilerinin \%46'sı (130) ve ikinci örneklem grubunu oluşturan mimarlık öğretim elemanlarının \%68'i (84) ev şartlarının mimarlıkta uygulamalı derslerde uzaktan eğitim için yeterli olduğunu belirtirken, \%30 (84) gibi bir orandaki öğrenci grubu ve öğretim elemanlarının \%20'si (25) ise ev şartlarının uygun olmadığını ifade etmiştir. Bu da öğrenciler arasında eğitim eşitsizliği yaratmakta olup uygulamalı derslerin uzaktan eğitimde devam ettirilebilmesi konusunda önemli bir tehdittir. Öğretim elemanlarının \%20'sinin (25) ev şartlarının uygun olmaması da, dersi veren ve öğreten kişinin konsantrasyon ve verimini etkileyecek bir faktör olmasıyla, ev şartları daha uygun olan öğretim elemanından ders alan öğrenciyle arada eşitsizlik yaratabilecektir. Ev şartlarının mimarlıkta uzaktan eğitim için uygun olmadığını belirten öğretim elemanlarının yaş aralıkları 25-34 (10), 35-44 (11) ve 45-54 (4) şeklindedir. Oranlamada ev şartları konusunda en çok sorun yaşayan gruplar sırasıyla 45-54, 35-44 ve 25-34 yaş aralığı şeklindedir.

Tablo 4. Öğrenci ve öğretim elemanlarına yöneltilen evde konsantrasyon sorunlarına ve ev şartlarının uygunluğuna dair soruların analizi

\begin{tabular}{|c|c|c|c|c|c|c|}
\hline \multirow[t]{2}{*}{ Öğrencilere ve Öğretim Elemanlarına Yöneltilen Sorular } & \multicolumn{3}{|c|}{ Öğrenciler } & \multicolumn{3}{|c|}{ Öğretim Elemanları } \\
\hline & $1-2(+)$ & 3 & $\begin{array}{c}4-5 \\
(-)\end{array}$ & $1-2(+)$ & 3 & $\begin{array}{l}4-5 \\
(-)\end{array}$ \\
\hline $\begin{array}{l}\text {-öğrenciler için- } \\
\text { Uzaktan eğitimde, derslere rahat ev ortamında girdiğim için, uygu- } \\
\text { lamalı derslerde konsantrasyon sorunu yaşadım. } \\
\text {-öğretim elemanları için- } \\
\text { Uzaktan eğitimde, derslere öğrencilerin ev ortamında girmesi ne- } \\
\text { deniyle, uygulamalı derslerde onları derse full konsantre tutmakta } \\
\text { sorun yaşadım. }\end{array}$ & 183 & 37 & 64 & 79 & 13 & 31 \\
\hline $\begin{array}{l}\text {-öğrenciler için- } \\
\text { Uzaktan eğitimde, evimin rahat ortamında ders yapmak, uygula- } \\
\text { mäı derslerdeki performansımı olumlu etkiledi. } \\
\text {-öğretim elemanları için- } \\
\text { Uzaktan eğitimde, öğrencilerin ev ortamında ders yapmaları, uygu- } \\
\text { lamalı derslerdeki performanslarını olumlu etkiledi. }\end{array}$ & 78 & 59 & 147 & 16 & 43 & 64 \\
\hline $\begin{array}{l}\text {-öğretim elemanları için- } \\
\text { Uzaktan eğitimde, evimden ders yapmak, uygulamalı derslerdeki } \\
\text { performansımı olumlu/iyi yönde etkiledi. }\end{array}$ & - & - & - & 31 & 32 & 60 \\
\hline $\begin{array}{l}\text {-öğrenciler için- } \\
\text { Uzaktan eğitimde derslerdeki konsantrasyon sürem azaldı ve dik- } \\
\text { katim daha hızlı dağıldı. } \\
\text {-öğretim elemanları için- } \\
\text { Uzaktan eğitimde öğrencilerin derslerdeki konsantrasyon süresi } \\
\text { azaldı ve dikkatleri daha hızlı dağıldı. }\end{array}$ & 194 & 31 & 59 & 78 & 31 & 14 \\
\hline $\begin{array}{l}\text {-öğretim elemanları için- } \\
\text { Uzaktan eğitimde uygulamalı derslerdeki konsantrasyon sürem } \\
\text { azaldı ve dikkatim daha hızlı dağıldı. }\end{array}$ & - & - & - & 38 & 15 & 70 \\
\hline Uzaktan eğitimde ev şartlarım, dersleri yürütmek için yeterliydi. & 130 & 70 & 84 & 84 & 14 & 25 \\
\hline
\end{tabular}

Uzaktan eğitimin yüz yüze eğitimden en büyük farklarından olan çevrimiçi toplantı uygulamaları üzerinden yapılan derslerin kaydediliyor oluşu, uzaktan eğitimin hem çok büyük bir fırsatı hem de büyük bir tehdidi olabilmektedir. Çünkü öğrenciler, bunu kendi yararlarına kullanırsa, aynı dersi defalarca dinleyerek öğrendikleri bilgi- leri pekiştirebilir, gözlerinden kaçan bir nokta varsa eksiğini giderebilir. Yüz yüze eğitimde öğretim elemanı dersi ders programında tanımlanmış zaman diliminde bir kereye mahsus olacak şekilde anlatırken, öğrencinin onu dinleyip öğrenmek için tek bir seferlik şansı vardır. Bu bağlamda uzaktan eğitim, derslerin kaydedilebiliyor olması yönüyle çok büyük bir fırsattır. Ancak öte yandan 
öğrenciler, istedikleri zaman dersi tekrar dinleyebileceklerini düşünerek, dersin işlendiği anda dersten daha rahat kopabilmekte ve rehavete kapılabilmektedir.

Bu bağlamda öncelikle mimarlık öğretim elemanlarına mimarlıkta uzaktan eğitimde uygulamalı dersler için çevrimiçi toplantı programları dışında başka bir uzaktan öğretim yönetim sistemi kullanıp kullanmadıkları ve senkron derslerini kaydedip kaydetmedikleri sorulmuştur ve bu sorulara verilen yanıtlar analiz edilmiştir (Tablo 5). Öğretim elemanlarının \%42'si (52), derslerindeki ödev, sınav ve teslimler için çevrimiçi toplantı programları dışında bir uzaktan öğretim yönetim sistemi kullanmakta olup, \%94'ü (116) uygulamalı senkron derslerini kaydetmektedir.
Öğrencilerin \%66'sı (187) uzaktan eğitimde derslerin kaydediliyor olmasının fırsatından yararlanarak, dersleri tekrar tekrar izlemiş ve uygulamalı derslerdeki performanslarını yükseltmiştir. Öğretim elemanlarının \%42'sine (52) göre de kaydedilen derslerin tekrar izlenebilirliği, uygulamalı derslerde öğrencinin performansını arttırmıştır. Öğrenci-öğretim elemanı yorumları oran bazında incelendiğinde, öğrencilerin performans yükselmesi konusunda öğretim elemanlarına göre daha optimisttik olduğu anlaşılmaktadır. Öğrencilerin \%57'si (163) dersin işlendiği gerçek anda, dersin kaydediliyor olmasına güvenerek derste rehavete kapıldıklarını ve koptuklarını belirtmiştir. Öğretim elemanlarının da \%65'i (80) de öğrencilerin derslerin kaydediliyor olmasından dolayı rehavete kapıldıklarını düşünmektedir. Bu konuda öğrenci ve öğretim elemanları yakın cevaplar vererek, hemfikir olduğu görünmektedir.

Tablo 5. öğrenci ve öğretim elemanlarına yöneltilen derslerin kaydedilmesine yönelik soruların analizi

\begin{tabular}{|c|c|c|c|c|c|c|}
\hline \multirow{2}{*}{ Öğrencilere ve Öğretim Elemanlarına Yöneltilen Sorular } & \multicolumn{3}{|c|}{ Öğrenciler } & \multicolumn{3}{|c|}{ Öğretim Elemanları } \\
\hline & $1-2(+)$ & 3 & $\begin{array}{c}4-5 \\
(-)\end{array}$ & $1-2(+)$ & 3 & $\begin{array}{c}4-5 \\
(-)\end{array}$ \\
\hline $\begin{array}{l}\text {-öğrenciler için- } \\
\text { Uzaktan eğitimde derslerin kaydediliyor olması sayesinde dersleri } \\
\text { ve kritiklerimi tekrar dinleyebiliyor olmam, uygulamalı derslerdeki } \\
\text { başarımı arttırdı. } \\
\text {-öğretim elemanları için- } \\
\text { Uzaktan eğitimde derslerin kaydediliyor olması sayesinde öğren- } \\
\text { cilerin dersleri ve kritikleri tekrar dinleyebiliyor olmaları, öğrenci- } \\
\text { lerin uygulamalı derslerdeki başarılarını arttırdı. }\end{array}$ & 187 & 46 & 51 & 52 & 39 & 32 \\
\hline -öğrenciler için- & & & & & & \\
\hline $\begin{array}{l}\text { Uzaktan eğitimde derslerin kaydedilmesiyle ve daha sonra tekrar } \\
\text { izleme imkanım olduğunu bilmem nedeniyle uygulamalı dersler } \\
\text { esnasında rehavete kapıldım ve dersten koptuğum zamanlar oldu. } \\
\text {-öğretim elemanları için- } \\
\text { Uzaktan eğitimde derslerin kaydedilmesiyle ve daha sonra tekrar } \\
\text { izleme imkanlarının olduğunu bilmeleri nedeniyle öğrenciler, uy- } \\
\text { gulamalı dersler esnasında rehavete kapıldı ve dersten koptukları } \\
\text { zamanlar oldu. }\end{array}$ & 163 & 45 & 76 & 80 & 21 & 22 \\
\hline
\end{tabular}

51 farklı üniversiteden çalışmaya dahil olan öğretim elemanlarının mimarlıkta uzaktan eğitim için kullandıkları çevrimiçi toplantı programlarında çeşitlilik bulunmaktadır. Öğretim elemanlarının \%32'si (39) yalnızca Microsoft Teams ve \%27'si (33) Zoom programlarını kullanırken, \%9'u (11) Microsoft Teams ve Zoom'u birlikte kullanmaktadır. \%2'lik (3) bir kısım Sakai, \%6 (7) oranda Adobe Connect, \%9'u (11) Blackboard, \%2'si (2) Google Meet, \%3'ü (4) Perculus, \%1'i (1) de Big Blue Button kullanıyor olup, geri kalan \%10'luk (12) kısım ise Microsoft Teams, Zoom ve diğer programlardan en az birini kullanmak suretiyle üç farklı çevrimiçi toplantı programını birlikte kullanmaktadır. Öğretim elemanlarının \%36'sı (31), mimarlıkta uzaktan eğitimde uygulamalı derslerde kullandıkları çevrimiçi toplantı programlarının yeterli olduğu belirtmiştir. Yeterli bulmayan öğretim elemanlarından, mimarlıkta uzaktan eğitimde uygulamalı derslerde kullandıkları çevrimiçi toplantı programlarında eğer eksik gördükleri ve onları zorlayan yanları varsa belirtmeleri istenmiştir. Bu bağlamda verilen benzer yanıtlar birer başlık altında toplanarak, çevrimiçi programlardaki ana zorluklar halinde Tablo 6'daki belirlenmiştir. 
Tablo 6. Öğretim elemanlarına göre mimarlıkta uzaktan eğitimde uygulamalı derslerde kullanılan çevrimiçi toplantı programlarda eksik gördükleri ve zorlayıcı yanlar

\begin{tabular}{|c|}
\hline eksikliği \\
\hline Eş zamanlı olarak bütün öğrencileri aynı anda görememek, aynı anda sınırlı sayıda öğrenciyi görebilme \\
\hline Ekran paylaşma vb. konularda yeterince hızlı olunamaması \\
\hline Denetim isteme/alma sürecindeki yavaşlık \\
\hline Senkronizasyon problemi \\
\hline Dosya paylaşımında da mimarlık özelinde oluşturulan sunumlar ve diğer belgeler maksimum dosya boyutunu aşması \\
\hline Bilgisayar ortamında ekran üzerinden kritik verirken, el çizimi (Mouse ile) yapılmasındaki zorluklar \\
\hline Ders kayıtlarının sınırlı süre saklanması ve sonra silinmesi \\
\hline $\begin{array}{l}\text { Normalde sınıfta/atölyede sınav esnasında telefonları toplayabiliyorken ve sınav güvenliğini daha rahat sağlayabiliyorken, tüm eğitim } \\
\text { ve sınavların dijital ortamda olmasıyla sınav güvenliğinin sağlamanın zorluğu }\end{array}$ \\
\hline Hiçbir mimarlık eğitimi bilgisi ve geçmişi olmayan birinci sınıflarla çevrimiçi araçlarla ders yapmak \\
\hline $\begin{array}{l}\text { Çevrimiçi toplantı uygulamalarında dersin kaydediliyor olmasıyla öğrencinin tembelliğe yönelmesi, stüdyo ortamında öğrenci not tutar- } \\
\text { ken, öğrenmeye çalışırken, çevrimiçi ortamda herkesin kamerasını açtırılsa bile örneğin } 80 \text { kişilik sınıfta herkesi aynı anda görme } \\
\text { imkanının olmaması, öğrencilerin ders esnasında isterlerse uyuyabilmeleri, isterlerse başka faaliyetlerde bulunabilmeleri, öğretim ele- } \\
\text { manı odaklıığa dönüş }\end{array}$ \\
\hline $\begin{array}{l}\text { Uygulamalı derslerin adım adım anlatılmaya çalışılırken ders anlatım kısımlarının normalden çok uzaması ve uygulama kısmından } \\
\text { vakit çalınmak zorunda kalınması }\end{array}$ \\
\hline $\begin{array}{l}\text { Çevrimiçi uygulamalarda programların kısıtlılıkları nedeniyle uygulama projeleri ve tasarım stüdyosu projelerine verilen kritiklerin çok } \\
\text { uzaması, geç saatlere kadar sürmesi }\end{array}$ \\
\hline $\begin{array}{l}\text { Her ne kadar mimarlık eğitimi bilgisayar sahibi olmayı gerektirse de, geleneksel eğitimde 1. Sınıf el çizimi ve maketle götür } \\
\text { sınıftır. 1. Sınıfların çoğunun bilgisayarı olmaması ve ellerindeki bilgisayara göre küçük ekranlı telefonlardan dersi takip etmek z } \\
\text { kalmaları }\end{array}$ \\
\hline
\end{tabular}

Çalışmanın bir diğer aşamasında öğrenci ve öğretim elemanlarına dijitalleşmeye dair sorular yöneltilmiş ve bu sorulara verilen yanıtlar analiz edilmiştir (Tablo 7). Sürekli olarak teknolojik ve dijital imkanların kullanılmasıyla birlikte uzaktan eğitimde öğrencilerin \%50'si (143) kendilerini hem bilgisayar yeterlilikleri, hem de 2 boyutlu CAD çizim ve 3 boyutlu modellemeler konusunda geliştirdiklerini belirtmiştir ki çağımızın teknoloji ve dijitalleşme çağı olduğu düşünüldüğünde aslında uzaktan eğitim bu noktada çok büyük bir fırsattır. Öğretim elemanlarının \%48'i (59) de kendilerini uzaktan eğitimle birlikte bilgisayar/teknoloji kullanımı ve yeterlilikleri bağlamında geliştirmiştir.

Yüz yüze eğitimde, her kritik öncesinde derse gelmeden çıktı almak durumunda kalan öğrenciler, uzaktan eğitimle birlikte dijitalleşmenin nimetlerinden biri olarak çıktı almaktan kurtulmuştur. Öğrencilerin \%68'i (192) kritikler ve teslimler için çıktı almak zorunda olmamaktan memnunlar.

Bununla birlikte, yüz yüze eğitimde ödev ve teslimler bazen unutulabilmekte, ödev ve sınavlar bazen yalnızca sözlü olarak öğrencilere ders esnasında duyurulabilmekte, teslim gün ve saatleri kaçırılabilmekteyken; uzaktan eğitimle birlikte dijital teknolojilerin teslimleri hatırlatması gibi özellikleri sayesinde öğrencilerin \%35'i (100) uzaktan eğitimde sınav, ödev ve teslimlerini çok daha rahat takip edebildiklerini belirtmiştir. Öğretim elemanlarının \%39'u (48) da mimarlık öğrencilerin ödev, sınav ve teslimlerini uzaktan eğitimde daha rahat takip edebildiklerini düşünmektedir. Ancak öğretim elemanlarının yalnızca \%29'u (36) çevrimiçi toplantı programlarının ödev, sınav ve jüri değerlendirmeleri yüz yüze eğitime göre daha kolay olduğunu düşünürken, çoğunluğu oluşturan \%56'lık (69) bir kesim, uygulamalı derslerdeki değerlendirmelerin yüz yüze eğitime göre çok daha zorlayıcı olduğunu belirtmektedir.

Üniversitenin dijital olarak devam etmesiyle trafik ve kötü hava şartları gibi üniversite kampüsüne gelmekte yaşanabilecek çevresel problemlerin hiçbiriyle karşı karşıya kalmamak öğrencilerin derslere devamlıığını arttırmış olabilir öngörüsüyle iki örneklem grubuna da öğrencilerin uzaktan eğitimde derslere devamlılığında artış olup olmadığı sorulmuş olup, öğrencilerin \%33'ü (93) ve öğretim elemanlarının \%11'i (14) arttığını belirtmektedir. Bu oranlardan anlaşıldığı kadarıyla özellikle öğretim elemanlarının gözlem ve yorumları doğrultusunda, yüz yüze eğitimde derslere devam eden/devamsızlık yapan öğrencilerin, uzaktan eğitimde de benzer tutum içerisinde olduğu çıkarımı yapılabilmektedir.

Mimarlıkta uzaktan eğitimin bir fırsatı olabileceği öngörülerek öğrencilere, dijital eğitimde ders öğretim elemanlarına yüz yüze eğitime göre daha rahat ulaşıp ulaşamadıkları sorulmuştur. Öğrencilerin \%34'ü (97) bu soruya olumlu cevap verirken, \%33'ü (93) de olumsuz şekilde yanıtlamıştır. Öğretim elemanlarında ise olumlu yanıt verme oranı çok daha yüksek olup, \%50'lik (62) bir oranla öğretim elemanları, yüz yüze eğitime göre uzaktan eğitimde öğrencileriyle daha rahat haberleşmiştir.

Mimarlıkta uygulamalı derslerin uzaktan eğitimde öğretilmesinde öğrencilerin \%58'i (166) proje derslerinde kritikleri anlamakta, öğretim elemanlarının \%66'sı (81) 
proje derslerinde kritik vermekte zorlanmıştır. Öğrencilerin \%64'ü (181) ise teknik/yapı gibi uygulamalı derslerde uygulamaya yönelik yeni bilgileri öğrenmekte, öğretim elemanlarının \%68'i (84) de öğretmekte zorlanmıştır. Ayrıca öğretim elemanlarının \%55'i (68) mimarlık öğrencilerinin teknik/yapı gibi uygulamalı derslerde uygulamaya yönelik yeni bilgileri öğrenmekte zorlandığını belirtmiştir. Bu nedenle, şu noktada mimarlığın uygulamalı derslerinin uzaktan eğitimde en verimli noktaya gelemediği görülmektedir. Ders öğretim elemanlarının proje derslerindeki kritikler ve yapı/teknik dersler için yeni ders işleyiş yöntemleri geliştirmesi mimarlıkta uygulamalı derslerin uzaktan eğitimdeki sürdürülebilirliği için önem taşımaktadır.
Küreselleşen dünyanın bir çıktısı olarak mimarlık mesleği ve eğitim sistemi de son yıllarda buna adapte olmaya başlamıştır (Nalçakan ve Polatoğlu, 2008). Uzaktan eğitime geçilmesi, eğitim sisteminin küreselleşmeye adaptasyonunu arttıracak bir unsurdur. Bu bağlamda öğrencilerin \%67'si (190), mimarlıkta uygulamalı derslerin uzaktan eğitimle devam etmesi halinde başka şehir ve ülkelerdeki mimarlık bölümlerinden de ders almak, öğretim elemanlarının \%66'sı (81) ders vermek istemektedir. Bu bağlamda, bu konu mimarlıkta uygulamalı derslerin uzaktan eğitimdeki sürdürülebilirliğinin önemli bir avantajıdır.

Tablo 7. Öğrenci ve öğretim elemanlarına yöneltilen dijitalleşmeye yönelik soruların analizi

\begin{tabular}{|c|c|c|c|c|c|c|}
\hline \multirow[t]{2}{*}{ Öğrencilere ve Öğretim Elemanlarına Yöneltilen Sorular } & \multicolumn{3}{|c|}{ Öğrenciler } & \multicolumn{3}{|c|}{ Öğretim Elemanları } \\
\hline & $1-2(+)$ & 3 & $\begin{array}{c}4-5 \\
(-)\end{array}$ & $1-2(+)$ & 3 & $\begin{array}{c}4-5 \\
(-)\end{array}$ \\
\hline $\begin{array}{l}\text { Uygulamalı dersler için çıktı almak zorunda olmamaktan memnu- } \\
\text { num. }\end{array}$ & 192 & 44 & 48 & - & - & - \\
\hline $\begin{array}{l}\text {-öğrenciler için- } \\
\text { Uzaktan eğitim sayesinde bilgisayar kullanımında, bilgisayar des- } \\
\text { tekli çizim ve/veya modelleme programlarında kendimi geliştirdim. } \\
\text {-öğretim elemanları için- } \\
\text { Uzaktan eğitim sayesinde bilgisayar yeterliliklerimi arttırdım. }\end{array}$ & 143 & 66 & 75 & 59 & 26 & 38 \\
\hline $\begin{array}{l}\text {-öğrenciler için- } \\
\text { Uzaktan eğitimde ödevlerimi, sınav ve jürilerimi daha rahat takip } \\
\text { edebildim. } \\
\text {-öğretim elemanları için- } \\
\text { Uzaktan eğitimde öğrenciler, ödevleri, sınav ve jürileri daha rahat } \\
\text { takip edebildi. }\end{array}$ & 100 & 60 & 124 & 48 & 36 & 39 \\
\hline $\begin{array}{l}\text { Uzaktan eğitimde uygulamalı derslerde ödev, sınav ve jüri değer- } \\
\text { lendirmeleri yüz yüze eğitime göre daha kolaydı. }\end{array}$ & - & - & - & 36 & 18 & 69 \\
\hline $\begin{array}{l}\text {-öğrenciler için- } \\
\text { Uzaktan eğitimde derslere daha rahat devamlılık gösterdim. } \\
\text {-öğretim elemanları için- }\end{array}$ & 93 & 48 & 143 & - & - & - \\
\hline Uzaktan eğitimde öğrencilerin derslere devamlılığı arttı. & - & - & - & 14 & 34 & 75 \\
\hline $\begin{array}{l}\text {-öğrenciler için- } \\
\text { Uzaktan eğitimde ders yürütücülerine daha rahat eriştim. } \\
\text {-öğretim elemanları için- } \\
\text { Uzaktan eğitimde öğrencilerle daha rahat haberleştim. }\end{array}$ & 97 & 94 & 93 & 62 & 19 & 42 \\
\hline $\begin{array}{l}\text {-öğrenciler için- } \\
\text { Uzaktan eğitimde uygulamalı derslerde, ders yürütücüsünün tek- } \\
\text { nik ve tasarımsal kritiklerini anlamakta zorlandım. } \\
\text {-öğretim elemanları için- } \\
\text { Uzaktan eğitimde uygulamalı derslerde, öğrenciler proje kritikle- } \\
\text { rimi anlamakta yüz yüze eğitime göre daha zorlandı. }\end{array}$ & 166 & 59 & 59 & 75 & 20 & 28 \\
\hline $\begin{array}{l}\text {-öğretim elemanları için- } \\
\text { Uzaktan eğitimde uygulamalı derslerde, öğrencilere proje kritiği } \\
\text { vermekte yüz yüze eğitime göre daha zorlandım. }\end{array}$ & - & - & - & 81 & 13 & 29 \\
\hline $\begin{array}{l}\text {-öğrenciler için- } \\
\text { Uzaktan eğitimde uygulamalı derslerde, teknik, proje ve yapı ders- } \\
\text { lerindeki uygulamaya yönelik yeni bilgileri öğrenmekte zorlandım. } \\
\text {-öğretim elemanları için- } \\
\text { Öğrenciler, uzaktan eğitimde uygulamalı derslerde, teknik, proje } \\
\text { ve yapı derslerindeki uygulamaya yönelik yeni bilgileri öğren- } \\
\text { mekte zorlandı. }\end{array}$ & 181 & 45 & 58 & 68 & 23 & 32 \\
\hline
\end{tabular}




\begin{tabular}{|l|ccc|}
\hline $\begin{array}{l}\text {-öğretim elemanları için- } \\
\text { Uzaktan eğitimde uygulamalı derslerde konu/çizim/detay anlat- } \\
\text { mak, yüz yüze eğitime göre daha zordu. }\end{array}$ & - & - & 84 \\
\hline $\begin{array}{l}\text { Şartlar normale döndüğünde mimarlık eğitimi uzaktan devam } \\
\text { ederse, farklı şehir ve ülkelerdeki üniversitelerin mimarlık bölüm- }\end{array}$ \\
$\begin{array}{l}\text { lerinden de ders alabilmeyi (öğrenci)- ders verebilmeyi (öğretim } \\
\text { elemanı) istiyorum. }\end{array}$
\end{tabular}

Çalışmanın son aşamasında öğretim elemanlarından seçenek seçmeli şekilde uzaktan mimarlık eğitiminde yüz yüze eğitime göre daha kolay olan işlemleri seçmeleri istenmiştir. Burada çıkan sonuçlar ise şaşırtıcı derece olumludur. Öğretim elemanlarının \%85'i (105) arşivin, \%82'si (101) teslim almanın, \%38'i (47) sınav değerlendirmesinin, \%31'i (38) jüri değerlendirmesinin, \%15'i (19) haftalık kritik vermenin, \%19'u (23) uygulamalı teknik/yapı derslerini öğretmenin, \%17'si (21) yazılı sınav yapmanın, \%3'ü (4) çizim sınavı yapmanın uzaktan mimarlık eğitiminde yüz yüze eğitime göre daha kolay olan işlemler olduğunu düşünmektedir. Bunun dışında bazı öğretim elemanları diğer seçeneğini seçerek, çalışmada sunulmayan ama kendilerinin görüşüne göre uzaktan mimarlık eğitiminin yüz yüze eğitime göre daha kolay olduğu konuları açıklamıştır (Tablo 8). Yalnızca bir öğretim elemanı, mimarlıkta uzaktan eğitimin yüz yüze eğitime göre hiçbir yönden kolaylığı olmadığını belirtmiş olup, geri kalan 122 kişi uzaktan eğitimin en az 1 konuda yüz yüze eğitime göre kolay olduğunu belirtmiştir.

Tablo 8. Öğretim elemanlarına göre mimarlıkta uzaktan eğitimin yüz yüze eğitime göre daha kolay olan diğer özellikleri

\begin{tabular}{|l|}
\hline $\begin{array}{l}\text { Yüz yüze eğitimde arkada oturan öğrencilerin sunumu tam görememesi ama uzaktan eğitimde herkesin eşit şekilde sunumları } \\
\text { görebilmesi }\end{array}$ \\
\hline Öğrencilere toplu duyuru yapma \\
\hline $\begin{array}{l}\text { Üniversite kampüsüne uzak oturan öğrencinin de yakın oturan öğrenciden bir farkı olmadan, mesafeler önemsizleşerek derse } \\
\text { kolayca katılabilmesi }\end{array}$ \\
\hline Öğrencilerin, diğer öğrencilerin de kritiklerini dinleyebilmesi \\
\hline Doküman ve bilgi paylaşımının daha hızlı ve pratik olması \\
\hline $\begin{array}{l}\text { Proje kritiğinin dijital teknik çizim ve modellemeler üzerinden verilmesi sonucunda senkronize kritikler esnasında öğrencile- } \\
\text { rin anlık düzeltme yapabilmesi }\end{array}$ \\
\hline Öğrencilere literatürden örnekleri anlık bulup gösterebilme ve interaktif sunumlar yapabilme \\
\hline
\end{tabular}

Öğrenci ve öğretim elemanlarına, pandemi bittiğinde ya da şiddeti azalıp hayatlar yeni normale tam anlamıyla dönüştüğünde, mimarlık eğitimine uzaktan mı yüz yüze mi devam etmeyi tercih edecekleri sorulmuştur ve öğrencilerin \%84'ü (238) ve öğretim elemanlarının \%35'i (43) yüz yüze eğitimi tercih etmiştir. Öğretim elemanlarının \%48'i (59) hibrit eğitim modelinin getirilmesi gerektiğini düşünmektedir.
Bu çalışmada mimarlık öğrenci ve öğretim elemanlarının perspektifinden bakıldığında, mimarlık uzaktan eğitiminde uygulamalı derslerin sürdürülebilirliği konusunda hem internet/elektrik altyapısı, hem dijital ve teknolojik imkanlardaki kısıtlılık hem de eşzaman derslerin yapıldığı çevrimiçi toplantı programlarındaki eksiklik ve aksaklıklara rağmen öğrencilerin \%59'u (66) ve öğretim elemanlarının \%31'i (38) mimarlıkta uygulamalı derslerde uzaktan eğitimden memnundur (Tablo 9).

Tablo 9: Öğrenci ve öğretim elemanlarının mimarlıkta uygulamalı derslerde uzaktan eğitimden memnuniyet durumu

\begin{tabular}{|c|c|c|c|c|c|c|}
\hline \multirow[t]{2}{*}{ Öğrencilere ve Öğretim Elemanlarına Yöneltilen Sorular } & \multicolumn{3}{|c|}{ Öğrenciler } & \multicolumn{3}{|c|}{ Öğretim Elemanları } \\
\hline & $\begin{array}{l}1-2 \\
(+)\end{array}$ & 3 & $\begin{array}{c}4-5 \\
(-)\end{array}$ & $\begin{array}{l}1-2 \\
(+)\end{array}$ & 3 & $\begin{array}{c}4-5 \\
(-)\end{array}$ \\
\hline Mimarlıkta uzaktan eğitimden memnunum. & 66 & 53 & 165 & 38 & 35 & 50 \\
\hline
\end{tabular}

\section{SONUÇLAR}

Mimarlık eğitimi, merkezinde proje dersleri bulunan ve bu dersleri çeşitli teorik ve uygulamalı derslerin desteklediği bir eğitim modeli olarak üniversitelerde stüdyo olarak isimlendirilmiş ve içerisinde çizim masalarının bulunduğu sınıflarda gerçekleştirilmektedir. Mimarlık eğitiminde, ders yürütücüsünün monolog şeklinde tek yönlü ders anlatımı ve öğrencinin de dinleyici konumunda kaldığı eğitim modellerinden ziyade, daha çok öğrencinin aktif biçimde dahil olduğu bir eğitim modelinin daha uygun olduğu anlaşılmış ve uygulanmaktadır. Bu bağlamda mimarlık öğrencileri yaparak ve deneyimleyerek öğrenmekte, sınıf arkadaşları ve ders yürütücüleriyle birlikte çözümler üretmekte, yeri geldiğinde ekip çalışması 
yapmakta ve yalnızca ders yürütücülerinden değil sınıftaki diğer arkadaşlarından da bu ekip çalışmaları aracılığıyla öğrenmektedir.

Mart 2020 yılında tüm dünyayla birlikte Türkiye'de de COVID-19 pandemisi nedeniyle zorunlu olarak uzaktan eğitime geçilmiş olup, tüm üniversitelerde ve tüm bölümlerde uzaktan eğitim süreci başlamıştır. Teorik ağırlıklı bir müfredata ve eğitim modeline sahip olan disiplinlerde uzaktan eğitim çok zorlayıcı olmamışsa da, mimarlık gibi uygulama ağırlıklı ve ders yürütücüsü-öğrenci, öğrenciöğrenci vb. etkileşimlerin çok önemli olduğu bir bölümde uzaktan eğitim ilk başta hem ders yürütücülerine hem de öğrencilere yabancı gelmiştir. Aslında yaklaşık 30 yıllık bir süreçte tasarım ve proje derslerinin uzaktan verilmesine dair çalışmalar yapılmıştır. Ancak bu çalışmalar çok kısıtlı kalmakla birlikte yalnızca proje derslerine odaklanmakta olup, mimarlık eğitiminde çok önemli bir yere sahip olan yapı-malzeme ve teknik çizim gibi dersleri kapsamamaktadır. Normal şartlarda ders esnasında öğrenciyle birebirde kritik verme şeklinde gerçekleşen proje ve ders yürütücüsünün sınıfta tahtaya çizerek, maket üstünden vb. yaptığı teknik çizim ve yapı-malzeme dersleri, uzaktan eğitimde mimarlık eğitiminin en çok zorlayıcı olduğu alanlar olmuştur.

Bu çalışma; uzaktan eğitimle birlikte hem ders yürütücüleri hem de öğrenciler kendilerini bilgisayar yeterlilikleri konusunda geliştirmiştir ve geliştirmeye devam etmektedir. Uzaktan eğitimin zorlayıcı yanlarının ve dezavantajlarının yanında; arşivlemedeki kolaylık, öğrencinin fiziksel olarak sınıfın gerisinde mi yoksa tahtaya yakın mı olduğu eşitsizliğinin aksine uzaktan eğitimin sunumları tüm öğrencilere eşit şartlarda sunabilme gibi olumlu yanları olduğu da fark edilmiştir. Ayrıca, mimarlık eğitiminin doğası gereği etkileşim odaklı bir metotta işlenmesi, uzaktan eğitimin herkesi evlerde bireysel olmaya zorlamasına zıtmış gibi bir düşünce olsa da, aslında sınıf ortamında çoğunlukla ders yürütücüsü-öğrenci arasında ikili şekilde gerçekleşen proje kritikleri, uzaktan eğitimde tüm öğrencilerin dahil olup kritikleri dinleyip yorum yapabileceği bir halde gelişmektedir.

Uzaktan mimarlık eğitimi her ne kadar öğrencilere yabancı gelse ve zorlukları olsa da, öğrenciler uzaktan eğitimden memnun olmaya başlamıştır. Günümüzde teknolojik gelişmelere bağlı olarak eğitim yöntemlerinin de yeniliklere açık olması ve bunları eğitim kurumlarında uyguluyor olmak önemli ve zorunlu hale gelmiştir. Türkiye'de mimarlık eğitiminin 1883'te açılan Sanayi-i Nefise Mektebi'nde başladığı ve 2020 senesine kadar mimarlık eğitiminin 100 yılı aşkın bir süreyle yüz yüze yapıldığı düşünüldüğünde, bir senede uzaktan eğitimde bu noktaya gelinmesi bile dijitalleşme yolunda olumlu bir durum olarak görülebilmektedir. Özellikle altyapının geliştirilmesi ve çevrimiçi toplantı programlarının mimarlığın uygulamalı derslerine uygun sürümlerinin oluşturulması sonucunda, gelecek senelerde mimarlık uygulamalı derslerinin uzaktan şekilde çok rahat bir biçimde sürdürülebilmesi olası olmaktadır ve küresel düzeyde ortak bir eğitim kurulabilmesi bu yolla olabilecektir.

\section{KAYNAKLAR}

Aközer, E. (2019). Mimarın Özgürlüğü. Bauhaus: Modernleşmenin Tasarımı Türkiye'de Mimarlık, Sanat, Tasarım Eğitimi ve Bauhaus. Ed. Ali Altun, Esra Aliçavuşoğlu. İletişim Yayınları, 111-152.

Artun, A. (2018). Mimarlığı Parçalamak. Ed: Nur Altınyıldız Artun, Roysi Ojalvo. Arzu Mimarlığı, İletişim Yayınları, 9-12.

Bender, D.M. (2003). Interior Design Faculty Intentions to Adopt Distance Education. Journal of Interior Design, 29(12): 66-81.

Chickering, A.W., Gamson, Z.F. (1987). Seven Principles for Good Practice in Undergraduate Education. AAHE Bulletin, 3(1): 2-6.

Cini, M.A., Vilic, B. (1999). Online Teaching: Moving form Risk to Challenge. Syllabus, 12(10): 38-40.

Colquhoun, A. (2005). Mimari Eleştiri Yazıları, Şevki Vanlı Yayınları.

Dewey, J., Dewey, E. (1915). Schools of Tomorrow, E. P. Dutton \& Company, New York.

Doğan, D., Tüzün, H., Dağhan, G., Altıntaş, A., Ilgaz, H., Özdinç, F., Kayaduman, H., Özpala, N. (2012). Uzaktan Eğitimde Ders Tasarımı: Yüz Yüze Verilen Bir Dersin Uzaktan Eğitim Sürecine Hazır Hale Getirilmesi. New World Sciences Academy 7(2): 574-582.

Dutton, T.A. (1987). Design and studio pedagogy. Journal of architectural education, 41(1): 16-25.

Fichera, T.A. (2012). The Effectiveness of Distance Delivery Studios in Interior Design Education, Master Thesis. University of Nebraska, $74 \mathrm{p}$.

Frampton, K. (1996). Modern Architecture. Thames and Hudson, London.

Hasol, H., Polatoğlu, Ç. (2008). Türkiye'deki ve Dünyadaki Mimarlık Eğitiminin Karşılaştırmalı Analizi ile Küreselleşmenin Mimarlık Eğitimine Etkisinin İrdelenmesi. Megaron Dergisi, 3(1): 79-103.

Hejduk, J., (1999). The Juan Gris Problem Education of an Architect: A Point of view the Cooper Union School of Art \& Architecture 1964-1971,193-244, U. Franzen, A. P. Gomez, K. Shkapich (derl.), The Monacelli Yayınları, New York.

Keskin Balamir, A. (1985). Mimarlık Söyleminin Değişimi ve Eğitim Programları, Mimarlık Dergisi, 218(1): 9-15.

Keyser, M. W. (2000). Active Learning and Cooperative Learning: Understanding the Difference and Using Both Styles Effectively, Research Strategies, 17(1): 35-44.

Maciuika, J. (2019). Deutscher Werkbund ve Osmanlı İmparatorluğu: Birinci Dünya Savaşı Öncesinde Tasarım Reformu, Ekonomi Politikası ve Dış Politika. Bauhaus: Modernleşmenin Tasarımı Türkiye'de Mimarlık, Sanat, Tasarım Eğitimi ve Bauhaus, İletişim Yayınları, 35-66. 
Mun, B., Arslan Selçuk, S. (2018). Mimarlıkta Yaparak Öğrenme ve Bir Araştırma Ortamı Olarak Öğrencilerin Ürettiği Geçici Strüktürler. International Journal on Mathematics, Engineering and Natural Sciences, 2(1): 12-25.

Onur, D., Zorlu, T. (2017). Tasarım Stüdyolarında Uygulanan Eğitim Metotları ve Yaratıcılık İlişkisi. The Turkish Online Journal of Design Art and Communication, 7(4): 542-555.

Özkâr, M. (2019). Soyut Düşünme ve Yaparak Öğrenme: Temel Tasarım Eğitiminin Amerika'daki Başlangıçları. Bauhaus: Modernleşmenin Tasarımı Türkiye'de Mimarlık, Sanat, Tasarım Eğitimi ve Bauhaus, Ed. Ali Altun, Esra Aliçavuşoğlu, İletişim Yayınları, 135-152.

Özsavaş Uluçay, N., Kaptan, B. (2018). İçmimarlık Mesleği ve Eğitim Tarihi. Akademik Sosyal Araştırmalar Dergisi, 80(1): 436-444.

Öztoprak, A. (2004). An Evaluation of Virtual Design Studio: A Course Between Middle East Techical University and Delft University of Technology. Orta Doğu Teknik Üniversitesi, Yüksek lisans tezi, $124 \mathrm{~s}$.

Shao, Y. J., Daley, L., Vaughan, L. (2007). Exploring Web 2.0 for Virtual Design Studio Teaching. Paper presented at Ascilite 2007 Conference.
URL-1 (2020). https://www.who.int/ emergencies/ diseases /novel-coronavirus-2019 /question-and answershub/q-adetail/q-acoronaviruses (Erişim Tarihi: 18.12.2020)

URL-2 (2020). http://im.gsf.marmara.edu.tr/en/general-info (Erişim Tarihi: 18.12.2020)

Vitruvius, (2005). Mimarlık Üzerine On Kitap, Şevki Vanlı Yayınları, İstanbul, $241 \mathrm{~s}$.

Wojtowicz, J. (1995). Virtual Design Studio. Hong Kong: Hog Kong University Press. https://books.google.co.in/books (Erişim Tarihi: 20.12.2020).

TDK, (2011). Türkçe Sözlük (Tek Cilt) Kolektif, Türk Dil Kurumu Yayınları, İstanbul.

Yiğit, T., Bingöl, O., Armağan, H., Aruğaslan, E., Çolak, R., Yakut, G., Çivril, H. (2010). Uzaktan Eğitimde Yeni Bir Yaklaşım: e-stüdyo, Muğla Üniversitesi, Akademik Bilişim, (1): 97-105.

Yorgancıoğlu, D. (2019). 20. Yüzyılın İlk Yarısında Bauhaus Fikirlerinin Amerika Kıtasındaki Yolculuğu. Bauhaus: Modernleşmenin Tasarımı Türkiye'de Mimarlık, Sanat, Tasarım Eğitimi ve Bauhaus. Ed. Ali Altun, Esra Aliçavuşoğlu, İletişim Yayınları, 153-168. 